\title{
Discovery of Negative-Sense RNA Viruses in Trees Infected with Apple Rubbery Wood Disease by Next-Generation Sequencing
}

Michael E. Rott ${ }^{\dagger}$ and Prasad Kesanakurti, Canadian Food Inspection Agency, Sidney Laboratory, North Saanich, British Columbia, V8L1H3, Canada; Constanze Berwarth, Julius-Kuehn Institute, 69221 Dossenheim, Germany; Heidi Rast, Ian Boyes, and James Phelan, Canadian Food Inspection Agency, Sidney Laboratory; and Wilhelm Jelkmann, Julius-Kuehn Institute

\begin{abstract}
Apple rubbery wood is a disease of apple found around the world, often associated with Apple flat limb disease, and regulated in many countries. Despite its long history in apple cultivation, the disease's causal agent has remained elusive. In this study, next-generation sequencing (NGS) was used to identify and characterize several related novel viral agents from apple rubbery wood-infected plants, which have been named Apple rubbery wood virus (ARWV) 1 and 2. Additional specimens with apple rubbery wood disease tested positive by polymerase chain reaction with primers designed to ARWV 1 and 2 genomic RNA segments. In an NGS-

based screening of over 100 Malus and 100 Prunus specimens from a collection of virus-infected trees, only one Malus specimen was found to be infected with ARWV not known to be infected with the disease, which strongly suggests that ARWV is not commonly found in Malus spp. or other fruit trees. The two viruses are most closely related to members of the order Bunyavirales. Three RNA segments (large, medium, and small) were characterized and the viruses likely represent a new genus under the family Phenuiviridae, with a suggested name of Rubodvirus (Rubbery wood virus).
\end{abstract}

Apple rubbery wood disease (ARWD) is distributed worldwide (Cropley et al. 1963) and was first observed as early as 1935 on the variety Lord Lambourne in England (Wallace et al. 1944). In addition to apple, it can also occur as a latent infection of pear (Campbell 1966). In some countries, it is considered to be of minor importance but, in regions where sensitive varieties such as Lord Lambourne, Gravenstein, Golden Delicious, Gala, Splendour, and others are grown, it can be considered of major importance (Chamberlain et al. 1971; Waterworth and Fridlund 1989). It has been reported that ARWD can reduce fruit yield by up to $30 \%$ in apple and $50 \%$ in pear (Lemoine and Michelesi 1990). Infected trees are more susceptible to frost damage and infection with additional viruses can increase susceptibility to Phytophthora spp. and aggravate symptom expression (Chamberlain et al. 1971; Zawadzka et al. 1979). Despite a long history of disease characterization, very little is known about the causal agent of ARWD. It was first suggested that the disease might be caused by a virus based on symptoms and graft transmissibility (Wallace et al. 1944). As recently as 2016, Jakovljevic et al. (2016), using nextgeneration sequencing (NGS) of ribosomal depleted total RNA from ARWD-infected plants, were unable to confirm the presence of a virus associated with the disease. It has also been suggested that the disease may be associated with a phytoplasma or bacteria (Beakbane et al. 1971; Bertaccini et al. 1998; Minoui and Cracium 1982) but other studies have failed to support these findings (Menzel et al. 2003; Poggi Pollini et al. 1995; Smart et al. 1996). To date, the only reliable method of detecting ARWD is by inoculation onto a sensitive indicator host such as Lord Lambourne (EPPO 1999). ARWD is characterized by unusual flexibility of twigs and smaller branches due to lack of rigidity caused by decreased lignification of xylem vessels and fibers (Németh 1986), which can take 1 to 3 years to develop.

${ }^{\dagger}$ Corresponding author; M. E. Rott; E-mail: mike.rott@inspection.gc.ca

Funding: This work is supported by funding from the Genomics Research and Development Initiative, Protection of Canadian biodiversity and trade from the impacts of global change through improved ability to monitor invasive alien and quarantine species, and the Canadian Food Inspection Agency, project SID-P-1701.

Accepted for publication 15 December 2017.

(C) Her Majesty the Queen in Right of Canada, as represented by the Minister of Agriculture and Agri-Food Canada, 2018.
After this time, trees may grow normal wood and symptoms can completely disappear (Waterworth and Fridlund 1989). For an inexperienced diagnostician, these symptoms may be difficult to distinguish from the natural flexibility of Lord Lambourne saplings. An image of ARWD specimen 4622 in Gala (Fig. 1A) shows a fairly severe instance of the disease, with the main trunk bent almost 180 degrees. Several trees in this orchard showed similar symptoms. In trees where the upper trunk had been removed, drooping of the lower branches was very obvious. Other characteristic symptoms include soft and cheesy texture of the infected wood. These symptoms were attributed to the absence of lignin in the walls of xylem vessels and tracheids (Beakbane and Thompson 1945).

Apple flat limb disease (AFLD) was first noticed in Canada as early as 1887, in the United States in 1907, and in Australia in 1912 (McCrum et al. 1960). Based on symptomology, it was originally classified as a rough bark disease, similar to stem pitting, and thought to be caused by a virus (Thomas 1942). Linear depressions or flattening of branches and stems are observed in the sensitive varieties, in particular Gravenstein (Fig. 1B), and have also been observed in pear and quince (McCrum et al. 1960). Symptoms can develop into deep furrows and branches can become necrotic and brittle. Development of characteristic symptoms can be slow and variable, taking anywhere from 6 months to 8 years. Like ARWD, AFLD can be transmitted by grafting and budding but no natural vector has been identified. More recently, the causal agents of ARWD and AFLD have been thought to be the same (Waterworth and Fridlund 1989).

In this study, we reevaluate previously published NGS data (Jakovljevic et al. 2016) from an isolate of ARWD together with NGS data from several ARWD specimens, including a specimen infected with AFLD and one infected with both ARWD and AFLD, using alternative bioinformatic tools, to search for a possible viral pathogen and report the finding of two to three novel viruses. Polymerase chain reaction (PCR) primers were designed and used to screen additional specimens of ARWD from virus collections at the Canadian Food Inspection Agency (CFIA), Canada, and the Julius-Kuehn Institute, Germany. Finally, NGS data from 200 virus-infected fruit trees were screened for the presence of these viruses. Together, these results provide convincing evidence that Apple rubbery wood virus (ARWV) 1 and 2 are the causal agents of ARWD.

\section{Materials and Methods}

ARWD specimens. Twenty-four positive control specimens infected with ARWD or AFLD from collections in Germany (specimens R2 to R10, R12, C15, C16, C19, C20, C21, C23, C24, and 
C25) and CFIA (specimens 264, 355, 982, 4342, 4298, and 4622), were used in this study. An additional positive specimen, 1148, not previously suspected of being infected with ARWD, and the negative control specimen C30 were also included (Table 1). Samples of specimens R2 to R5 were obtained from a plant-protection service in Northern Germany in 2016, while R6 to R9 were received at the same time from the western part of Germany. These specimens were kept as old trees that had been indexed positive on Lord Lambourne more than two decades ago. Specimens R10, R12, C15, C19 to C 21, and C23 to C25 were all collected between 1977 and 1989 throughout Germany, indexed positive for ARWD, and maintained in the field without further propagation at the Julius-Kuehn Institute. Specimen C16 was the most recently indexed isolate in 2010, displaying typical symptoms on branches of Lord Lambourne.

From the CFIA collection, 4342 and 982 were obtained as known positive controls from Germany and the United States, respectively. Specimens 264 and 4298 were new variety imports from Japan and the United States which tested positive on Lord Lambourne. Specimen 4622 originated from an infected orchard in eastern Canada. (Table 1). Over 200 additional Malus and Prunus specimens from the CFIA virus collection, not known to be infected with ARWD or AFLD, were also screened in this study. One of these, 1148,

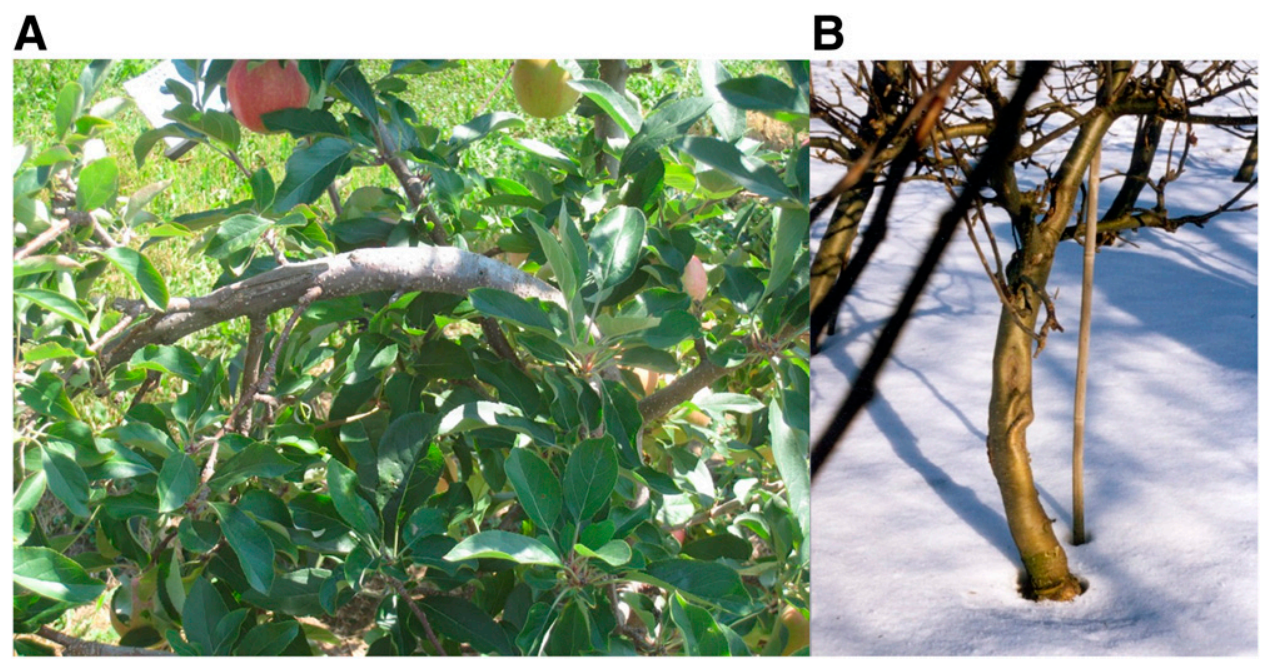

Fig. 1. A, Apple rubbery wood symptoms for isolate 4622 infected with Apple rubbery wood virus 1. B, Apple flat limb symptoms from an unknown isolate.

Table 1. Specimens (Spec) and polymerase chain reaction (PCR) results ${ }^{\mathrm{a}}$

\begin{tabular}{|c|c|c|c|c|c|c|c|c|c|c|c|c|c|c|c|c|c|c|}
\hline \multirow[b]{2}{*}{ Spec } & \multirow[b]{2}{*}{ Coll } & \multirow[b]{2}{*}{ Index } & \multirow[b]{2}{*}{ Prop } & \multirow[b]{2}{*}{ Samp } & \multicolumn{4}{|c|}{ ARWV1 PCR primer } & \multicolumn{9}{|c|}{ ARWV2 PCR primers } & \multirow[b]{2}{*}{ Origin $^{b}$} \\
\hline & & & & & A01 & A02 & A03 & A04 & A05 & A06 & A07 & A08 & A09 & A10 & A11 & A12 & A13 & \\
\hline R2 & $<1999$ & $<1999$ & 2012 & 2016 & $\cdots$ & $\cdots$ & $\ldots$ & $\cdots$ & + & + & $\ldots$ & $\cdots$ & + & $\cdots$ & $\ldots$ & + & $\cdots$ & Germany E \\
\hline R3 & $<1999$ & $<1999$ & 2014 & 2016 & + & + & $\ldots$ & + & $\ldots$ & $\ldots$ & $\ldots$ & $\ldots$ & $\ldots$ & $\ldots$ & $\ldots$ & $\ldots$ & $\ldots$ & Germany E \\
\hline R4 & $<1999$ & $<1999$ & 2014 & 2016 & + & $\ldots$ & $\ldots$ & + & + & + & $\ldots$ & $\ldots$ & + & $\ldots$ & $\ldots$ & + & $\ldots$ & Germany E \\
\hline R5 & $<1999$ & $<1999$ & $<1999$ & 2016 & $\ldots$ & $\ldots$ & $\ldots$ & $\ldots$ & + & + & $\ldots$ & $\ldots$ & + & $\ldots$ & $\ldots$ & + & $\ldots$ & Germany NRW \\
\hline R6 & $<1999$ & $<1999$ & $<1999$ & 2016 & $\ldots$ & $\ldots$ & $\ldots$ & $\ldots$ & + & + & $\ldots$ & $\ldots$ & + & $\ldots$ & $\ldots$ & + & $\ldots$ & Germany NRW \\
\hline R7 & $<1999$ & $<1999$ & $<1999$ & 2016 & $\ldots$ & $\ldots$ & $\ldots$ & $\ldots$ & $+\mathrm{s}$ & + & + & $\ldots$ & + & $\ldots$ & $\ldots$ & + & $\ldots$ & Yermany NRW \\
\hline R8 & $<1999$ & $<1999$ & $<1999$ & 2016 & $\ldots$ & $\ldots$ & $\ldots$ & $\ldots$ & $\ldots$ & + & $\ldots$ & $\ldots$ & + & $\ldots$ & $\ldots$ & $+s$ & $\ldots$ & Germany NRW \\
\hline R9 & $<1999$ & $<1999$ & $<1999$ & 2016 & $\ldots$ & $\ldots$ & $\ldots$ & $\ldots$ & $\ldots$ & + & $\ldots$ & $\ldots$ & + & $\ldots$ & $\ldots$ & + & $\ldots$ & Germany NRW \\
\hline R10 & 1979 & 1987 & 2011 & 2016 & $\ldots$ & $\ldots$ & $\ldots$ & $\ldots$ & + & + & $\ldots$ & $\ldots$ & $\ldots$ & + & + & + & $+s$ & jermany Han \\
\hline R12 & 1979 & 1987 & 1992 & 2016 & $\ldots$ & $\ldots$ & $\ldots$ & $\ldots$ & $+\mathrm{s}$ & + & + & + & + & + & $+\mathrm{s}$ & $+\mathrm{s}$ & $+\mathrm{s}$ & ermany Han \\
\hline $\mathrm{C} 15$ & 1982 & 1982 & 2010 & 2016 & $\ldots$ & $\cdots$ & $\ldots$ & $\ldots$ & + & $\ldots$ & $\ldots$ & $\cdots$ & + & $\ldots$ & $\ldots$ & $\ldots$ & & Germany L \\
\hline $\mathrm{C} 16$ & 2010 & 2010 & 2011 & 2016 & $\ldots$ & $\ldots$ & $\ldots$ & $\ldots$ & $\ldots$ & $\ldots$ & + & $\ldots$ & $\ldots$ & $\ldots$ & $\ldots$ & + & $\ldots$ & Germany K \\
\hline $\mathrm{C} 19$ & 1989 & 1989 & 2012 & 2016 & $\ldots$ & $\ldots$ & $\ldots$ & $\ldots$ & + & + & $\ldots$ & $\ldots$ & + & $\ldots$ & $\ldots$ & + & $\ldots$ & Germany Han \\
\hline $\mathrm{C} 20$ & 1989 & 1989 & 1992 & 2016 & $\ldots$ & $\ldots$ & $\ldots$ & $\ldots$ & + & + & $\ldots$ & $\ldots$ & + & $\ldots$ & $\ldots$ & + & $\ldots$ & Germany Han \\
\hline $\mathrm{C} 21$ & 1977 & 1984 & 1998 & 2016 & $\ldots$ & $\ldots$ & $\ldots$ & $\ldots$ & + & $\ldots$ & $\ldots$ & $\ldots$ & + & $\ldots$ & $\ldots$ & + & + & Germany \\
\hline $\mathrm{C} 23$ & 1977 & 1984 & 1998 & 2016 & $\ldots$ & $\ldots$ & $\ldots$ & $\ldots$ & $+\mathrm{s}$ & + & $\ldots$ & $\ldots$ & + & $\ldots$ & $\ldots$ & + & $\ldots$ & Germany Hol \\
\hline $\mathrm{C} 24$ & 1977 & 1987 & 1998 & 2016 & $\ldots$ & $\ldots$ & $\ldots$ & $\ldots$ & $\ldots$ & $\ldots$ & $\ldots$ & $\ldots$ & + & $\ldots$ & $\ldots$ & $\ldots$ & $\ldots$ & Germany Hol \\
\hline $\mathrm{C} 25$ & 1986 & 1986 & 2012 & 2016 & $\ldots$ & $\ldots$ & $\ldots$ & $\ldots$ & $+\mathrm{s}$ & + & + & + & + & $\ldots$ & + & $\ldots$ & $\ldots$ & Germany K-A \\
\hline $\mathrm{C} 30$ & $\ldots$ & $\ldots$ & 1992 & 2016 & $\ldots$ & $\ldots$ & $\ldots$ & $\ldots$ & $\ldots$ & $\ldots$ & $\ldots$ & $\ldots$ & $\ldots$ & $\ldots$ & $\ldots$ & $\ldots$ & $\ldots$ & Healthy control \\
\hline 264 & 1973 & 1975 & 1995 & 2014 & $\ldots$ & $\ldots$ & $\ldots$ & $\ldots$ & $\ldots$ & $\ldots$ & $\ldots$ & + & $\ldots$ & $\ldots$ & $\ldots$ & $\ldots$ & $\ldots$ & Japan \\
\hline 355 & 1972 & 1972 & 1972 & 2014 & & $\ldots$ & $\ldots$ & & + & $+s$ & $+\mathrm{s}$ & $+\mathrm{s}$ & & $+\mathrm{s}$ & $+s$ & $+\mathrm{s}$ & + & Unknown \\
\hline 982 & 1979 & 1979 & 1995 & 2014 & $+s$ & $+\mathrm{s}$ & $+s$ & $+\mathrm{s}$ & & $\ldots$ & $\ldots$ & + & & . & + & $\ldots$ & $\ldots$ & United States \\
\hline 1148 & 1982 & $\mathrm{n} / \mathrm{d}$ & 1982 & 2014 & + & + & + & + & $\ldots$ & $\ldots$ & $\ldots$ & $\ldots$ & $\ldots$ & $\ldots$ & $\ldots$ & $\ldots$ & $\ldots$ & United States \\
\hline 4298 & 2009 & 2012 & 2009 & 2014 & $\ldots$ & $\ldots$ & $\ldots$ & $\ldots$ & $\ldots$ & $\ldots$ & + & + & + & + & + & + & $\ldots$ & United States \\
\hline 4342 & 2009 & 2009 & 2009 & 2014 & + & + & + & + & $\mathrm{n} / \mathrm{d}$ & $\mathrm{n} / \mathrm{d}$ & $\mathrm{n} / \mathrm{d}$ & $\mathrm{n} / \mathrm{d}$ & $\mathrm{n} / \mathrm{d}$ & $\mathrm{n} / \mathrm{d}$ & $\mathrm{n} / \mathrm{d}$ & $\mathrm{n} / \mathrm{d}$ & $\mathrm{n} / \mathrm{d}$ & Germany \\
\hline 4622 & 2013 & 2013 & 2013 & 2014 & $\ldots$ & $\ldots$ & $\ldots$ & $\ldots$ & + & + & + & $\ldots$ & + & $\ldots$ & $\ldots$ & + & $\ldots$ & Canada \\
\hline
\end{tabular}

a Abbreviations: ARWV = Apple rubbery wood virus, Coll = year specimen was originally collected, Index = year specimen was initially tested positive for Apple rubbery wood disease or Apple flat limb disease, Prop = year that the propagation used for next-generation sequencing testing was created, $+=$ positive PCR result, $\mathrm{s}=$ sequenced amplicon, $<1999=$ before 1999 , and $\mathrm{n} / \mathrm{d}=$ not done.

${ }^{\mathrm{b}} \mathrm{E}=$ Ellerhoop, NRW= North Rhine-Westphalia, Han = Hanover, Hol = Holstein, L = Ladenburg, $\mathrm{K}=$ Karlshruhe, and K-A = Klein-Altendorf. 
originally from the United States, was found to be infected with ARWV 1. The only time 1148 was assayed for ARWD was in 1990, when it was inoculated onto a single Lord Lambourne tree and tested negative.

NGS and viral sequence detection and assembly. NGS data for R12 was obtained from Jakovljevic et al. (2016) along with a second set of data from isolate R7 used in the same study but which was not published. Double-stranded RNA (dsRNA) was isolated from specimens 355, 982, 1148, and 4342 (Kesanakurti et al. 2016) and pairedend 100-base reads were obtained using an Illumina HiSeq. All data sets were processed using the custom workflow NuVs in Virtool v1.8.5 (https://www.virtool.ca). Briefly, reads were first mapped to a database of known plant virus reference sequences in Virtool using Bowtie2 2.2.9 (Langmead and Salzberg 2012). Matched reads were discarded and remaining reads mapped to the Malus genome (Velasco et al. 2010) and also discarded. Remaining reads were assembled into contigs using SPAdes 3.6.2 (Bankevich et al. 2012), screened for open reading frames (ORF) larger than 100 bases, and translated into amino acid sequences. Amino acid sequences were then searched for characteristic viral protein motifs using HMMER 3.1b2 (Eddy 2011) and vFam Feb. 2014 build (Skewes-Cox et al. 2014). Contigs coding for amino acid sequences with a high match to known viral motifs were exported to CLC Genomics Workbench (version 10.0.1; Qiagen) for further genome assembly. Several small gaps in the NGS data were filled by designing flanking primers, amplifying the unknown sequences by PCR, and Sanger sequencing the PCR amplicons. CLC Genomics Workbench 10.0.1 was used for sequence analysis. The $5^{\prime}$ and $3^{\prime}$ random amplification of cDNA ends (RACE) was undertaken utilizing the 5'RACE kit (Invitrogen) according to the manufacturer's instructions using a dsRNA template isolated from specimen 355 and virus-specific primers complementary to the ARWV $2 \mathrm{Mb}$ segment ends. Viral sequences for the six specimens have the following GenBank accessions: 355 (MF062133-35), 982 (MF062125-29), 1148 (MF062130-32), 4342 (MF062136-38), R7 (MF062144-46), and R12 (MF062139-43).

PCR analysis of ARWV. PCR primers were designed using CLC Genomics Workbench. Sequences from R12 were used to design primers to ARWV $2 \mathrm{~L}, 2 \mathrm{Ma}, 2 \mathrm{Mb}, 2 \mathrm{Sa}$, and $2 \mathrm{Sb}$ segments, and sequences from 1148 were used to design primers to ARWV 1L, $1 \mathrm{M}$, and 1S. For PCR analysis, nucleic acids were obtained by either cetyltrimethylammonium bromide extraction (Jakovljevic et al.
2016) or silica capture (Rott and Jelkmann 2001), as described previously. Precipitated RNA was pelleted by centrifugation at $13,000 \mathrm{rpm}$ for $30 \mathrm{~min}$ at $4{ }^{\circ} \mathrm{C}$, washed with $70 \%$ ethanol, and resuspended in $25 \mu l$ of RNAse-free water.

Reverse-transcription PCR was carried out according to the manual of RevertAid Premium Reverse Transcription (Thermo Scientific) in thermal cycler GeneTouch (Bioer). The reaction mixture contained $1 \mu l$ of total nucleic acids, $1 \mu \mathrm{l}$ of Random Primer (100 ng/ $\mu \mathrm{l}$; Invitrogen), $1 \mu \mathrm{l}$ of dNTP mixture (each dNTP at $10 \mathrm{mmol} /$ liter), and $11.5 \mu \mathrm{l}$ of high-performance liquid chromatography (HPLC) water, and was incubated for $5 \mathrm{~min}$ at $65^{\circ} \mathrm{C}$. Then, $4 \mu \mathrm{l}$ of $5 \times$ PCR buffer (provided with RevertAid Premium Reverse Transcription; Thermo Scientific), containing $250 \mathrm{mM}$ Tris- $\mathrm{HCl}\left(\mathrm{pH} 8.3\right.$ at $\left.25^{\circ} \mathrm{C}\right), 375 \mathrm{mM} \mathrm{KCl}$, $15 \mathrm{mM} \mathrm{MgCl}_{2}, 50 \mathrm{mM}$ dithiothreitol, and $0.5 \mu \mathrm{l}$ of RevertAid Premium Reverse Transcription (Thermo Scientific), was added and incubated for $5 \mathrm{~min}$ at $25^{\circ} \mathrm{C}$ and $30 \mathrm{~min}$ at $50^{\circ} \mathrm{C}$, with an inactivating step of 5 min at $85^{\circ} \mathrm{C}$.

FastGene Taq DNA Polymerase (Nippon Genetics) together with provided buffer A $(1.5 \mathrm{mM} \mathrm{MgCl} 2)$ was used for PCR. Each PCR mixture contained $1.25 \mu 1$ of buffer A, $0.25 \mu l$ of dNTP (each dNTP at $10 \mathrm{mmol} /$ liter), $8.95 \mu \mathrm{l}$ of HPLC water, and $0.05 \mu \mathrm{l}$ of FastGene Taq DNA Polymerase in a final volume of $12.5 \mu \mathrm{l}$, with $1 \mu \mathrm{l}$ of template cDNA and $0.5 \mu \mathrm{l}$ of each of forward and reverse primers $(10 \mu \mathrm{M})($ Table 2$)$ used per reaction. PCR parameters were denaturation at $95^{\circ} \mathrm{C}$ for $2 \mathrm{~min}$, followed by 32 cycles of denaturation at $95^{\circ} \mathrm{C}$ for $20 \mathrm{~s}$, annealing at $50^{\circ} \mathrm{C}$ for $20 \mathrm{~s}$, and extension at $72^{\circ} \mathrm{C}$ for $30 \mathrm{~s}$ The final extension step was $72^{\circ} \mathrm{C}$ for $3 \mathrm{~min}$. Amplicons were electrophoresed on $1 \%$ agarose gels at $100 \mathrm{Vs}$ for 40 to $60 \mathrm{~min}$, stained with either ethidium bromide or GelGreen (Biotium), visualized under UV light, and photographed. Selected PCR amplicons were sequenced either directly or after TOPO cloning (Invitrogen) by Sanger sequencing to confirm specificity of the primers (Table 1).

\section{Results}

Nucleotide sequence comparisons. Novel viral RNA identified from the NGS data from apple trees infected with ARWD and AFLD were most closely related to the order Bunyavirales of negative-sense single-stranded RNA viruses (https://talk.ictvonline.org/taxonomy/). Three RNA segments were identified that correspond to the large (L), medium (M), and small (S) segments. Two distinct L and three

Table 2. Polymerase chain reaction primers for the detection of Apple rubbery wood virus 1 and 2, RNA segments

\begin{tabular}{|c|c|c|c|}
\hline Primer pair & ARWV segment & Primer name & Sequence $5^{\prime}-3^{\prime}$ \\
\hline \multirow[t]{2}{*}{$\mathrm{A} 01$} & $1 \mathrm{~L}$ & ARWaV-1L3639F & AGAACCAGCAATAGCCAC \\
\hline & & ARWaV-1L4058R & CTATCCTTATCTTTGCCTACTT \\
\hline \multirow[t]{2}{*}{$\mathrm{A} 02$} & $1 \mathrm{~L}$ & ARWaV-1L4842F & ATGGGAAGGCTTAGGGTGTTTAAC \\
\hline & & ARWaV-1L5230R & GGTACAGGGTTTGTAGATTACAGAG \\
\hline \multirow[t]{2}{*}{ A03 } & $1 \mathrm{~S}$ & ARWaV-1M479F & ATCAATCTCTGTTTTCCCTTATGT \\
\hline & & ARWaV-1M1177R & TACCATACTTTTGAATCTTTGTGC \\
\hline \multirow[t]{2}{*}{ A04 } & $1 \mathrm{M}$ & ARWaV-1S506F & TGCCAAAAGGATCTGAAGGA \\
\hline & & ARWaV-1S1039R & TTATTTGGCTATCTGATTGACGAA \\
\hline \multirow[t]{2}{*}{$\mathrm{A} 05$} & $2 \mathrm{~L}$ & ARWaV-2L258F & TGTGTCTCTTATGCAATCTCAGGTC \\
\hline & & ARWaV-2L747R & ATCTTCCACATGCTTGACGAC \\
\hline \multirow[t]{2}{*}{ A06 } & $2 \mathrm{~L}$ & ARWaV-2L3386F & GGGGAAGAGCATACAACCAACA \\
\hline & & ARWaV-2LR4081R & GCATTTAAGCATCCACCCAACTA \\
\hline \multirow[t]{2}{*}{ A07 } & $2 \mathrm{Sa}$ & ARWaV-2M567F & GCAGCATTTAAGCATTCAGGAT \\
\hline & & ARWaV-2M1342R & GATCTACTGCTTTGGGTCTTTGTG \\
\hline \multirow[t]{2}{*}{ A08 } & $2 \mathrm{Sb}$ & ARWaV-2M2_272F & ACACCGATTCAGACGATGCTC \\
\hline & & ARWaV-2M2_1061R & AAATGGCTGCCTACTTATCTCACA \\
\hline \multirow[t]{2}{*}{ A09 } & $2 \mathrm{Ma}$ & ARWaV-2S1_38F & AATTCGATCGGTTTTCTGGTAT \\
\hline & & ARWaV-2S1_682R & GCCACCCAATTCACTTCATC \\
\hline \multirow[t]{2}{*}{ A10 } & $2 \mathrm{Mb}$ & $\mathrm{ARWaV}-2 \mathrm{~S} 2 \_2 \mathrm{~F}$ & ATAGACCCCTCCACAACTCAGC \\
\hline & & ARWaV-2S2_512R & CGCAGTTCATCTCTATCCCATCT \\
\hline \multirow[t]{2}{*}{ A11 } & $2 \mathrm{Sb}$ & con20863_182F & ACACCGATTCAGACGATGCTC \\
\hline & & con20863_777Rc & TTCATTTATGGCCTTCCTTAGC \\
\hline \multirow[t]{2}{*}{ A12 } & $2 \mathrm{~L}$ & con708_178F & TGTGTCTCTTATGCAATCTCAGGT \\
\hline & & con708_666R & ATCTTCCACATGCTTGACGACT \\
\hline \multirow[t]{2}{*}{ A13 } & $2 \mathrm{Sb}$ & con20863_328F & GGATTAACAAGAGGAAAC \\
\hline & & con20863_808Rc & TAGTCCTAAGTTTTTGAA \\
\hline
\end{tabular}


distinct $\mathrm{M}$ and $\mathrm{S}$ segments were identified from the six apple specimens, suggesting at least two, possibly three related virus species (Table 3). Additional apple viruses were also found. All specimens, with the exception of R12, were infected with Apple stem pitting virus (ASPV). Specimens 982, 355, R7, and 4342 were also infected with Apple chlorotic leafspot virus (ACLSV), and 335 was also infected with Apple stem grooving virus (ASGV) (Table 3).

ARWV 1 was found in association with specimens 982,1148 , and 4342 (Table 3). The three ARWV 1 L segments were $7.2 \times 10^{3}$ nucleotides (nt) in length, with greater than $94 \%$ sequence identity. The $\mathrm{M}$ segments were $1.6 \times 10^{3} \mathrm{nt}$ in length, with greater than $94 \%$ identity, and the $\mathrm{S}$ segment ranged in size from $1.3 \times 10^{3} \mathrm{nt}$, with identities of greater than $90 \%$. A related virus was present in specimens $355, \mathrm{R} 7$, and R12 and as a mixed infection with isolate 982, referred to as ARWV 2. The four ARWV $2 \mathrm{~L}$ segments were 120 to $260 \mathrm{nt}$ longer than ARWV $1 \mathrm{~L}$, with sequence identities of greater than 97\%. The size difference between the L segments of ARWV 1 and 2 are primarily a result of bases in the $3^{\prime}$ noncoding region of the positive-sense viral RNA. Two distinct $M$ and S RNA segments are associated with ARWV 2, referred to as ARWV 2Ma, 2Mb, 2Sa, and $2 \mathrm{Sb}$. Isolate R7 contained a complement of $2 \mathrm{~L}, 2 \mathrm{Ma}$, and $2 \mathrm{Sa}$ segments; 355 contained $2 \mathrm{~L}, 2 \mathrm{Mb}$, and $2 \mathrm{Sa}$; and R 12 contained $2 \mathrm{~L}, 2 \mathrm{Ma}$, $2 \mathrm{Mb}, 2 \mathrm{Sa}$, and $2 \mathrm{Sb} \mathrm{RNA}$. For isolate 982, mixed infected with ARWV 1 , only $2 \mathrm{~L}$ and $2 \mathrm{Sb}$ segments could be detected. The two $2 \mathrm{Ma}$ segments are $1.6 \times 10^{3} \mathrm{nt}$ in size and share $97 \%$ identity, and the two $2 \mathrm{Mb}$ segments are slightly longer and share $96 \%$ identity. The three 2Sa segments are $1.5 \times 10^{3} \mathrm{nt}$ in length and share 95 to $98 \%$ identity, while the two $2 \mathrm{Sb}$ segments share $80 \%$ identity and are $1.3 \times 10^{3}$ and $1.1 \times 10^{3} \mathrm{nt}$ in size. The differences in sizes of the $2 \mathrm{Sa}$ and $2 \mathrm{Sb}$ segments are primarily due to insertions and deletions in the $3^{\prime}$ noncoding region of the positive-sense RNA.
ARWV 1 and $2 \mathrm{~L}$ segments are distantly related to each other, with nucleotide sequence identity of less than $63 \%$. Likewise, ARWV $1 \mathrm{M}, 2 \mathrm{Ma}$, and $2 \mathrm{Mb}$ segments are also distantly related (59 to $64 \%$ identity), as are the ARWV $1 \mathrm{~S}, 2 \mathrm{Sa}$, and $2 \mathrm{Sb}$ segments (51 to $61 \%$ identity). Sequence divergence between the $2 \mathrm{Ma} / 2 \mathrm{Mb}$ and $2 \mathrm{Sa} / 2 \mathrm{Sb}$ segments was similar to the difference between $1 \mathrm{M} / 2 \mathrm{M}$ and $1 \mathrm{~S} / 2 \mathrm{~S}$ segments and would suggest that the ARWV 2 is a reassortment of two ancestral species. No significant nucleotide sequence identity could be detected between ARWV L, M, and S segments with any known bunyavirus or other viral sequence available in GenBank using BLASTN. The $5^{\prime}$ and $3^{\prime}$ terminal sequences of the ARWV L, M, and $\mathrm{S}$ segments, as determined from the NGS sequence data, are conserved, with inverted complementary, characteristic of segmented negative-sense RNA genomes (Pettersson and von Bonsdorff 1975). The $5^{\prime}$ and $3^{\prime}$ RACE was undertaken for specimen 355, ARWV 2Ma segment which extended the $5^{\prime}$ and $3^{\prime}$ ends by $8 \mathrm{nt}$ while maintaining the inverted complementarity. The ends are similar to other bunyaviruses (Fig. 2).

Amino acid sequence comparisons. The L segments code for a single ORF, resulting in a $276-\mathrm{kDa}$ translation product of 2,380 and 2,377 amino acids for ARWV 1 and 2, respectively. The L protein contains the Pfam Bunya_RdRp motif (http://pfam.xfam.org) for a bunyavirus RNA-dependent RNA polymerase gene, and likely codes for the viral replicase protein (Argos 1988). This profile hidden Markov model (HMM), which is 742 amino acids in length, matched $\left(3.3 \times 10^{-39}<\right.$ e-value $\left.<1.53 \times 10^{-32}\right)$ the ARWV L protein sequence over most of the profile HMM from position 44 to 741 (Table 3). Identity between the ARWV $1 \mathrm{~L}$ proteins was greater than $95 \%$ and, for ARWV 2, greater than 97\%. Identity between the ARWV 1 and $2 \mathrm{~L}$ proteins is $59 \%$ (Fig. 3). The best BLASTP hit was to the recently sequenced phleboviruses Watermelon crinkle leaf

Table 3. Apple rubbery wood virus (ARWV) RNA segments for each of the six sequenced specimens ${ }^{\mathrm{a}}$

\begin{tabular}{|c|c|c|c|c|c|c|}
\hline Spec, ARWV segment & Segment (bases) & ORF size (aa) & Pfam match (AN, ID) & e-Value & Location (aa) & Other viruses \\
\hline \multicolumn{7}{|l|}{1148} \\
\hline $1 \mathrm{~L}$ & $7.2 \times 10^{3}$ & 2,380 & PF04196.11 Bunya-RdRp & $2.2 \times 10^{-06}, 2.5 \times 10^{-33}$ & $559-819,783-1,223$ & \\
\hline $1 \mathrm{M}$ & $1.6 \times 10^{3}$ & 391 & PF01107.11 MP (CL0571) & $2.3 \times 10^{-14}$ & $97-255$ & ASPV \\
\hline $1 \mathrm{~S}$ & $1.3 \times 10^{3}$ & 291 & PF05733.10 Tenui_N & $1.2 \times 10^{-18}$ & $13-242$ & \\
\hline \multicolumn{7}{|l|}{4342} \\
\hline $1 \mathrm{~L}$ & $7.2 \times 10^{3}$ & 2,380 & PF04196.11 Bunya-RdRp & $1.0 \times 10^{-37}$ & $564-1,223$ & ASPV \\
\hline $1 \mathrm{M}$ & $1.6 \times 10^{3}$ & 391 & PF01107.11 MP (CL0571) & $5.3 \times 10^{-15}$ & $78-247$ & ACLSV \\
\hline $1 \mathrm{~S}$ & $1.3 \times 10^{3}$ & 291 & PF05733.10 Tenui_N & $2.4 \times 10^{-19}$ & $13-242$ & \\
\hline \multicolumn{7}{|c|}{-1} \\
\hline $1 \mathrm{~L}$ & $7.2 \times 10^{3}$ & 2,380 & PF04196.11 Bunya-RdRp & $3.3 \times 10^{-39}$ & $564-1,223$ & \\
\hline $1 \mathrm{M}$ & $1.6 \times 10^{3}$ & 391 & PF01107.11 MP (CL0571) & $6.0 \times 10^{-15}$ & $85-247$ & ASPV \\
\hline $1 \mathrm{~S}$ & $1.3 \times 10^{3}$ & 291 & PF05733.10 Tenui_N & $3.7 \times 10^{-19}$ & $13-242$ & ACLSV \\
\hline $2 \mathrm{~L}$ & $7.4 \times 10^{3}$ & 2,377 & PF04196.11 Bunya-RdRp & $7.5 \times 10^{-32}$ & $552-1,212$ & \\
\hline $2 \mathrm{Sb}$ & $1.1 \times 10^{3}$ & 285 & PF05733.10 Tenui_N & $1.7 \times 10^{-18}$ & $14-243$ & \\
\hline \multicolumn{7}{|l|}{355} \\
\hline $2 \mathrm{~L}$ & $7.4 \times 10^{3}$ & 2,377 & PF04196.11 Bunya-RdRp & $1.5 \times 10^{-32}$ & $552-1,212$ & ASPV \\
\hline $2 \mathrm{Mb}$ & $1.6 \times 10^{3}$ & 394 & PF01107.11 MP (CL0571) & $3.6 \times 10^{-12}$ & $72-251$ & ACLSV \\
\hline $2 \mathrm{Sa}$ & $1.5 \times 10^{3}$ & 289 & PF05733.10 Tenui_N & $3.9 \times 10^{-22}$ & $12-245$ & ASGV \\
\hline \multicolumn{7}{|c|}{-1} \\
\hline $2 \mathrm{~L}$ & $7.3 \times 10^{3}$ & 2,377 & PF04196.11 Bunya-RdRp & $2.6 \times 10^{-32}$ & $547-1,212$ & \\
\hline $2 \mathrm{Ma}$ & $1.6 \times 10^{3}$ & 378 & PF05733.10 Tenui_N & $2.0 \times 10^{-12}$ & $77-247$ & \\
\hline $2 \mathrm{Mb}$ & $1.6 \times 10^{3}$ & 394 & PF01107.11 MP (CL0571) & $3.7 \times 10^{-12}$ & $78-251$ & \\
\hline $2 \mathrm{Sa}$ & $1.5 \times 10^{3}$ & 289 & PF01107.11 MP (CL0571) & $3.9 \times 10^{-22}$ & $12-245$ & \\
\hline $2 \mathrm{Sb}$ & $1.3 \times 10^{3}$ & 287 & PF05733.10 Tenui_N & $8.6 \times 10^{-18}$ & $13-243$ & \\
\hline \multicolumn{7}{|c|}{ (2) } \\
\hline $2 \mathrm{~L}$ & $7.4 \times 10^{3}$ & 2,377 & PF04196.11 Bunya-RdRp & $4.4 \times 10^{-32}$ & $540-1,212$ & ASPV \\
\hline $2 \mathrm{Ma}$ & $1.6 \times 10^{3}$ & 378 & PF01107.11 MP (CL0571) & $2.2 \times 10^{-12}$ & $77-247$ & ACLSV \\
\hline $2 \mathrm{Sa}$ & $1.5 \times 10^{3}$ & 289 & PF05733.10 Tenui_N & $6.5 \times 10^{-22}$ & $12-245$ & \\
\hline
\end{tabular}

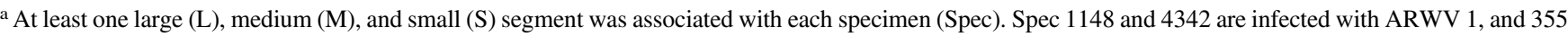
and R7 are infected with ARWV 2 and have the same S segment (2Sa) but with different M segments (2Ma and 2Mb). R12 is also infected with ARWV 2 with both S segments (2Sa and $2 \mathrm{Sb}$ ) and both $\mathrm{M}$ segments (2Ma and 2Mb). Spec 982 is a mixed infection consisting of a full complement of ARWV 1 (1 L, 1M, and $1 \mathrm{~S})$ and a partial complement of ARWV 2 (2 L and 2Sa) and lacks a 2M segment. Each segment size in nucleotide bases as well as size in amino acids (aa) of translation products. $\mathrm{ORF}=$ open reading frame. A single Pfam match was detected for each segment. For each Pfam match the accession number (AN) and identification (ID) are given along with individual e-values and the location of the Pfam match within the translation product. Additional viruses were present in all specimens: Apple stem pitting virus (ASPV), Apple stem grooving virus (ASGV), and Apple chlorotic leaf spot virus (ACLSV). 
associated virus 2 (GenBank accession ASY01343.1, e-value $=4 \times 10^{-90}$ ) and Blacklegged tick phlebovirus 4 (GenBank accession ASU47549.1, e-value $=4 \times 10^{-95}$ ).

The $\mathrm{M}$ segment codes for a single ORF with a translation product of $45 \mathrm{kDa}$. Identities within $1 \mathrm{M}, 2 \mathrm{Ma}$, and $2 \mathrm{Mb}$ translation products are greater than $98 \%$, whereas identities between the M segments range from 58 to $68 \%$ (Fig. 4). The ARWV M segment is considerably shorter than typical bunyavirus $M$ segments and no significant sequence homology could be detected between the 45-kDa product and sequences in GenBank using BLASTP (e-value =0.2). A Pfam search resulted in a best match with the plant virus family of movement proteins, PF01107.11, clan CL0571, with an e-value of $2.2 \times 10^{-12}$ to $6.0 \times 10^{-15}$ (Table 3). It is possible that the ARWV M segment codes for the viral movement protein.

The S segment also codes for a single ORF with a $32-\mathrm{kDa}$ translation product. Identity within the $1 \mathrm{~S}$ translation products was greater than $97 \%, 2 \mathrm{Sb}$ products was $97 \%$ and 2 Sa products was $98 \%$. Identity between $2 \mathrm{Sa}$ and $2 \mathrm{Sb}$ translation products was 77 to $78 \%$ whereas identity between $2 \mathrm{~S}$ and $1 \mathrm{~S}$ products was lower (66 to $68 \%$ ). Limited homology was detected using BLASTP between the

A

ARWV $2 \mathrm{Mb}$

3 ' UGUGUUUCUGGGGGAGGU . . . . . . 1111|| 1|||||| 1|| 5 ' ACACATAGACCCC-UCCA. ......

B

\begin{tabular}{|c|c|c|}
\hline ARWV 2Mb & $5^{\prime}$ & ACACAUAGAC-CCCUCCA ....... UGGAGGGGGUCUUUGUGU \\
\hline WCLaV & $5^{\prime}$ & ACACAUAGAACCCAUAAA . . . . . . UUGAGAGTUCUUUGUGU \\
\hline RVFV & $5^{\prime}$ & ACACAAAGGCGCCCAAUC . . . . . . UUUGGGCGGUCUUUGUGU \\
\hline TOSV & $5^{\prime}$ & ACACAGAGAGGCCCAAAU . . . . . . . UUGGGGCGGUCUUUGUGU \\
\hline RSV & $5^{\prime}$ & ACACAUAGUCAGAGGAAA . . . . . . UCCUCUGGACUUUGUGU \\
\hline
\end{tabular}

Fig. 2. Apple rubbery wood virus (ARWV) terminal sequences. A, Panhandle structure formed by the $3^{\prime}$ and $5^{\prime}$ termini of ARWV $2 M b$ segment. B, Comparison of $5^{\prime}$ and $3^{\prime}$ termini of ARWV 2 Mb segment with other bunyaviruses. WCLaV = Watermelon crinkle leaf associated virus (unclassified bunyavirus), RVFV = Rift valley fever virus (Phlebovirus), TOSV = Toscana virus (Phlebovirus), and RSV = Rice stripe virus (Tenuivirus).

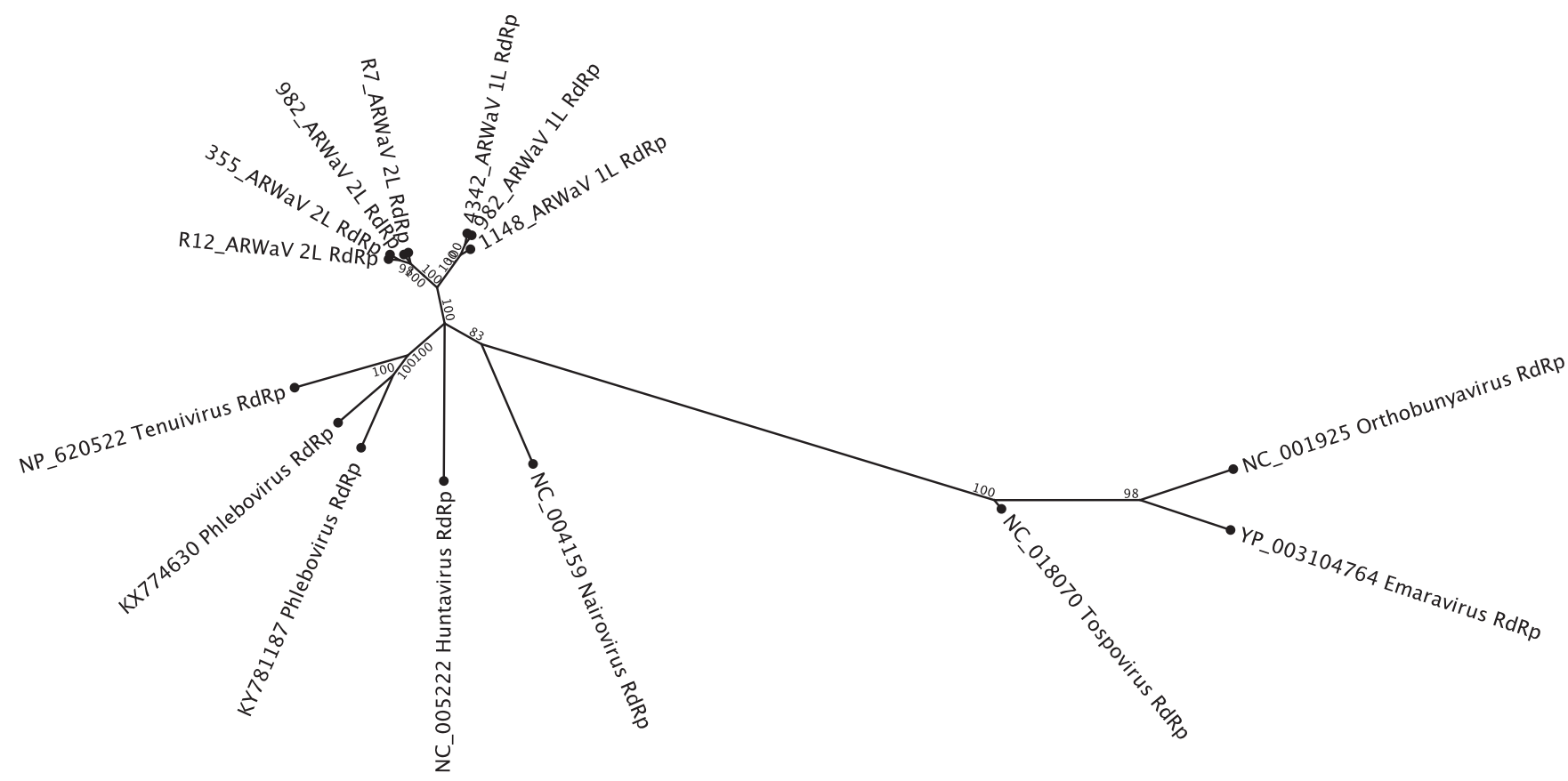

Note: Branches shorter than 0.0679 are shown as having length 0.0679

Fig. 3. Phylogenetic analysis of Apple rubbery wood virus (ARWV) large (L) protein, RNA-dependent RNA polymerase (RdRp) gene product with representative sequences of the Bunyavirales families. Representative sequences are indicated by a GenBank accession in the name. Alignments were generated with Create Alignment, CLCbio Genomics Workbench (version 10.0.1) with a gap cost $=6.0$, gap extension cost $=0.4$ and a free end gap cost. Maximum Likelihood Phylogeny 1.2 using the neighbor-joining method with a bootstrap analysis of 100 was used to create the radial trees. Branches with a bootstrap value of less than 70 were collapsed. ARWV 1 and 2 RdRp segregate into separate branches. Branches shorter than 0.0679 are shown to have a length of 0.0679 to better visualize the separation of the six ARWV L proteins. 
ARWV S products and the closest viral protein, phleobovirus Punta Toro virus nucleocapsid (N) protein (Fig. 5), with an e-value of $9 \times$ $10^{-26}$. A Pfam search gave a best match with the HMM family Teui_N, the Tenuivirus/Phleobovirus $\mathrm{N}$ protein with an e-value of $1.2 \times 10^{-18}$ to $3.9 \times 10^{-22}$ (Table 3 ). This HMM is 246 amino acids in length and matches the ARWV sequence from amino acid position 16 to 243 . It is likely that the ARWV S segment codes for the viral N protein.

PCR analysis of ARWD and AFLD specimens and screening for ARWV by NGS. PCR primer pairs were designed to the different viral RNA segments from specimens R12 and 1148 (Table 2) and tested against specimens of ARWD and AFLD (Table 1). Primers and PCR conditions were not optimized. Specificity for 11 of the 12 primer pairs was determined by Sanger sequencing of at least one amplicon (Table 1) to ensure that primer pairs amplified the expected virus-specific sequences. The majority of specimens tested positive to several primer pairs. Notable exceptions were specimens 264 and C24, which tested positive to only one primer pair targeting the $2 \mathrm{Sb}$ and $2 \mathrm{Ma}$ segments, respectively. In specimens infected with ARWV 2, the S segment could not always be detected by PCR, suggesting that this RNA may be less conserved or differs from the
R12 S segments. ARWV 1 was detected in five of the specimens, with primers $\mathrm{A} 01$ and $\mathrm{A} 04$ producing an amplification product for all five. ARWV 2 was detected in 22 of the specimens. Although none of the primer pairs designed to ARWV 2 was able to detect the virus in all specimens, most success was obtained using A09 (2Ma) and A12 (2L), A06 (2L), and A05 (2L). Additional optimization of PCR conditions may have improved these results but in silico analysis comparing primer sequences with fully sequenced viral RNA segments suggests that further primer design optimization is required (data not shown). The healthy apple control specimen C30 was negative for all primer pairs.

To determine the prevalence of ARWV, NGS data from over 100 Malus and 100 Prunus specimens, which had been previously analyzed for known tree fruit viruses, were reanalyzed for ARWV using Virtool. One apple specimen (1148) was found to be positive for ARWV 1 and was included in the NGS analysis.

\section{Discussion}

The causal agent of ARWD, first described in the 1940s (McCrum et al. 1960), remains unknown. In this study, specimens infected with ARWD, as well as an additional specimen not known to be infected

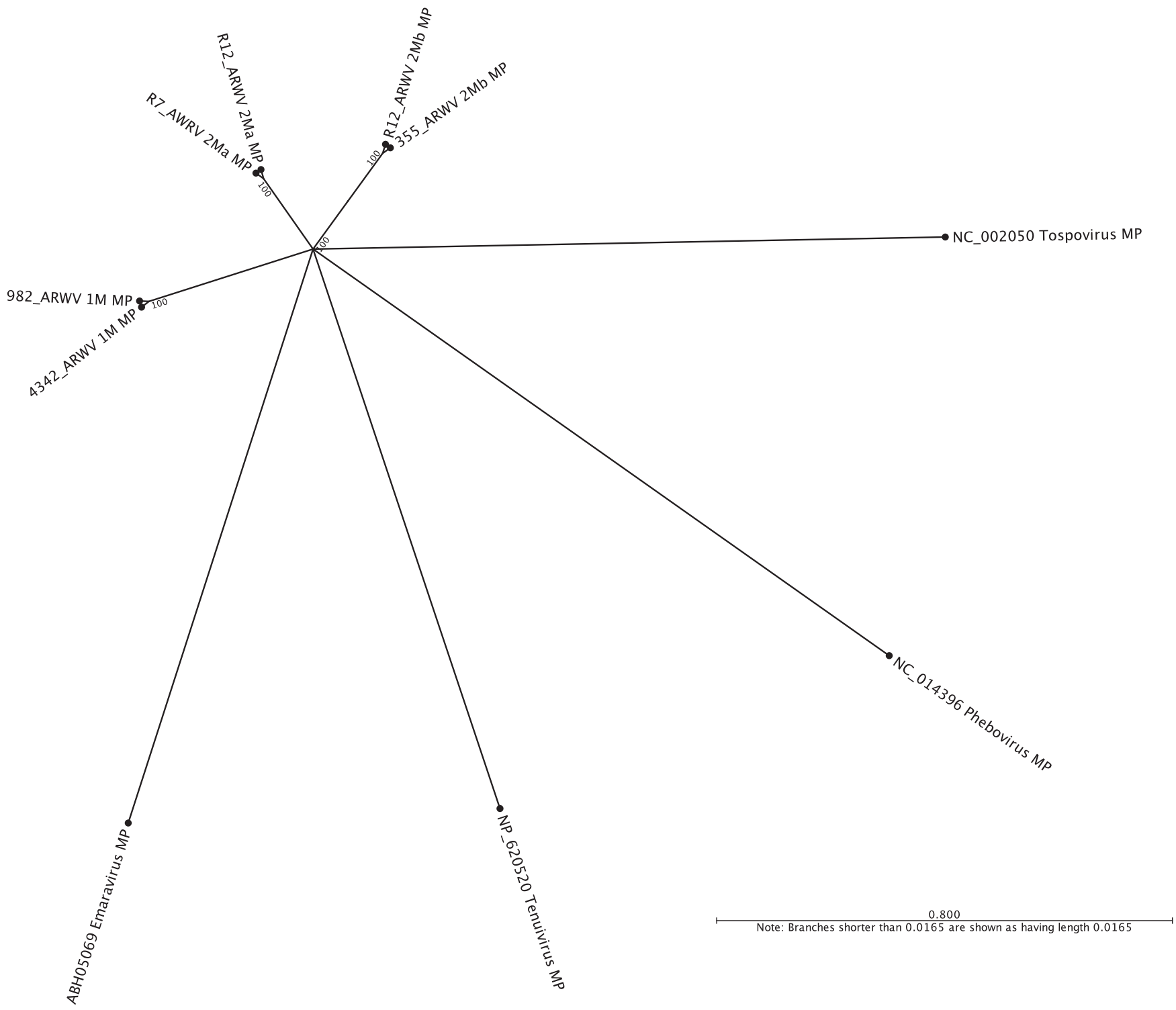

Fig. 4. Phylogenetic analysis of Apple rubbery wood virus (ARWV) nonstructural (NSm) protein, putative movement protein (MP) gene product with representative sequences of the Bunyavirales families. Representative sequences are indicated by a GenBank accession in the name. Alignments were generated with Create Alignment, CLCbio Genomics Workbench (version 10.0.1), with a gap cost $=6.0$, gap extension cost $=0.4$, and a free end gap cost. Maximum-Likelihood Phylogeny 1.2 using the neighbor-joining method with a bootstrap analysis of 100 was used to create the radial trees. Branches with a bootstrap value of less than 70 were collapsed. ARWV $1 \mathrm{M}$, 2Ma and $2 \mathrm{Mb}$ products segregate into separate branches. Branches shorter than 0.0165 are shown to have a length of 0.0165 to better visualize the separation of the six ARWV large $(L)$ proteins. 
with the ARWD, were analyzed using NGS techniques. L, M, and S genomic segments of two to three novel bunyaviruses named ARWV were sequenced and characterized from six specimens. Using PCR, ARWV was found in another 19 specimens, with ARWD providing a strong link between ARWD and ARWV.

With NGS, it is common to detect mycoviruses and other viruses that are associated with plants but do not infect the plant itself (Al
Rwahnih et al. 2011). In order to rule out the possibility that the bunyavirus sequences found in this study are not from a common virus associated with apple or other tree fruit, NGS data collected from over 100 Malus and 100 Prunus specimens (Rott et al. 2017) were rescreened for the presence of ARWV using a read mapping-based approach. This approach is significantly more sensitive than BLAST or profile HMM analysis of de novo assembled contigs. With the

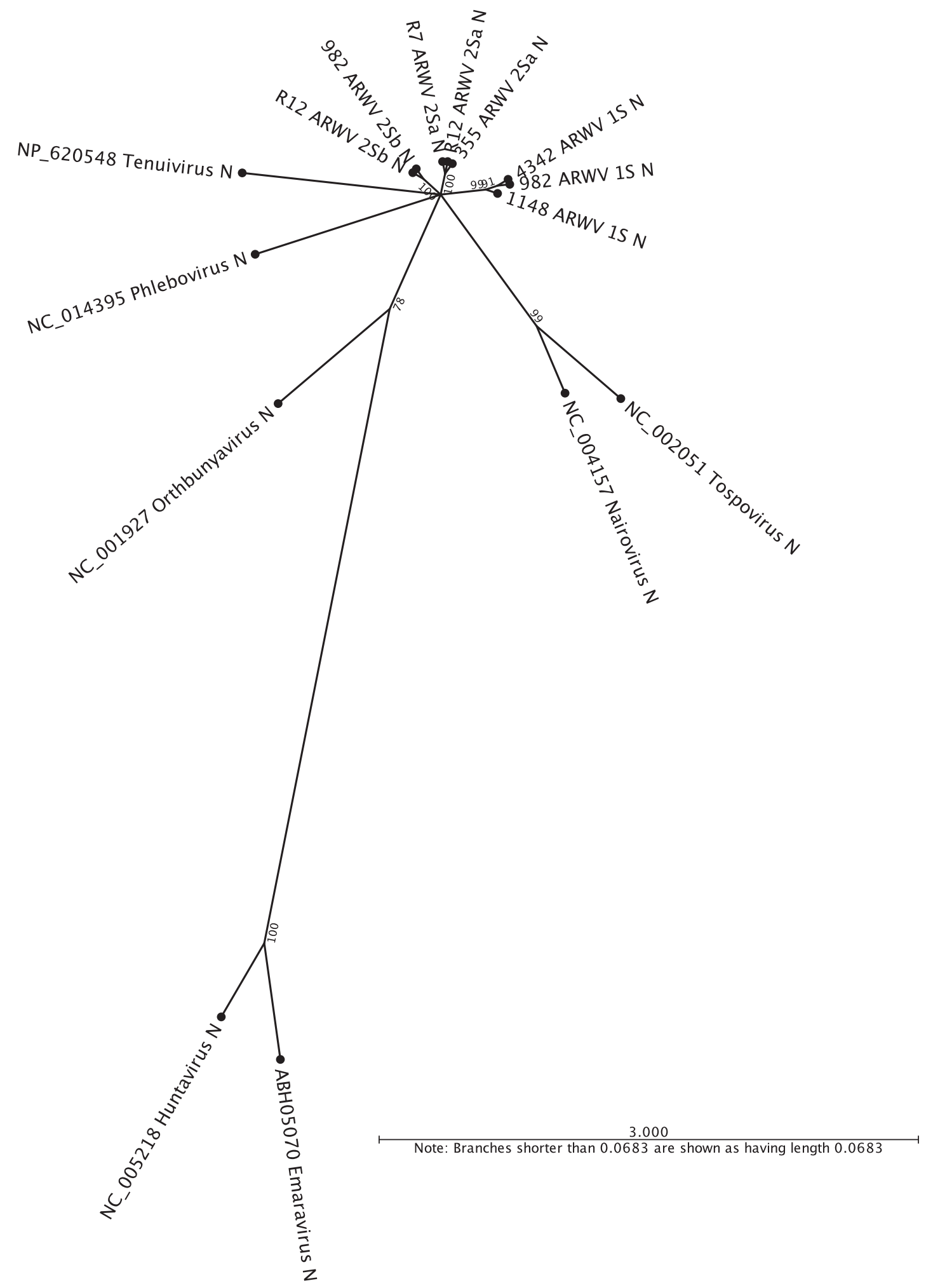

Fig. 5. Phylogenetic analysis of Apple rubbery wood virus (ARWV) small (S) segment putative nucleocapsid (N) protein product with representative sequences of the Bunyavirales families. Representative sequences are indicated by a GenBank accession in the name. Alignments were generated with Create Alignment, CLCbio Genomics Workbench (version 10.0.1), with a gap cost $=6.0$, gap extension cost $=0.4$, and a free end gap cost. Maximum-Likelihood Phylogeny 1.2 using the neighbor-joining method with a bootstrap analysis of 100 was used to create the radial trees. Branches with a bootstrap value of less than 70 were collapsed. ARWV 1S, 2Sa, and 2Sb products segregate into separate branches. Branches shorter than 0.0683 are shown to have a length of 0.0683 to better visualize the separation of the six ARWV coat proteins. 
exception of one specimen (1148), all plants were negative for ARWV. Specimen 1148 was assayed by grafting to a single Lord Lambourne tree 27 years ago and tested negative. Normally, multiple indicator trees are grafted when testing for ARWD by bioindexing to ensure diagnostic confidence, and it is possible that the disease was missed initially due to the small sample size.

Almost all available isolates of ARWD are mixed infected with one or more common apple viruses, with ASPV, ASGV, and ACLSV being the most common. This has resulted in the theory that ARWD symptoms are the result of mixed infections of known viruses. A notable exception to this theory is R12, which is free of known apple viruses and phytoplasma. ARWV is the only virus that could be detected in R12, providing convincing evidence that the ARWV is the causal agent of ARWD. Given the presence of ARWV in R12 and other ARWD-infected specimens and its complete absence in a large survey of noninfected specimens, it is appropriate to use the name ARWV as opposed to Apple rubbery wood associated virus.

Over the last decades, studies have suggested that ARWD is likely not caused by a phytoplasma, bacteria, or other known virus. The viruses described in this work are negative-sense bunyaviruses whose dsRNA titer is low relative to that of viruses with which they are commonly mixed infected. They also share little sequence similarity with other known bunyaviruses. Together, their low concentration and limited sequence similarity to known viruses could explain why they were not previously detected using standard dsRNA extraction and cloning methods in combination with BLAST searches or standard NGS-based approaches.

Because it was possible that ARWD and AFLD may be caused by the same virus (Waterworth and Fridlund 1989), two AFLD specimens were included in this study. Specimen 982 is known to be infected with both diseases and is infected with ARWV 1 and 2, while 355 is only known to have AFLD and is infected with ARWV 2. Although this sample size is to too small to make a definitive association, these results do support the possibility that ARWD and AFLD may be caused by the same viruses.

It is well known that the severity of rubbery wood disease symptoms can range from slight to severe, which has been attributed to strain variation (McCrum et al. 1960). Symptom variability could be explained by the diversity of segment reassortment, number of segments, or the mixing of virus species observed in the ARWD specimens sequenced. Only R12 is known to be free of other known viruses. ASPV, ASGV, and ACLSV infect many of the specimens and it is possible that the presence of these viruses affects symptom expression or severity of ARWV. Experiments are in progress to compare symptomology of several ARWD and AFLD specimens under identical field indexing conditions on Lord Lambourne and Gravenstein, over a period of several years, in order to correlate severity and type of disease with the virus genotypes present.

The PCR primers designed for 1148 and R12 gave variable results with other ARWD-infected specimens, which was not surprising after comparing primer sequences with the other sequenced viruses. Better primer design and PCR optimization based on more sequence data are required for the development of an effective diagnostic PCR assay. In particular, 264 and C24 could only be detected with one primer pair, A08 and A09, respectively, suggesting that these isolates may be more divergent and warrant further sequencing analysis. Nevertheless, the primers were demonstrated to be specific to ARWV based on confirmatory sequencing of PCR amplicons and the lack of amplification from a negative control. As expected, a single primer pair was unable to detect all specimens of the viruses; however, primer pairs targeting the ARWV L segment were the most successful (A01, A04, A05, A06, and A12).

ARWV can be categorized as two to three distinct virus species. ARWV 1 is present in specimen 4342 and ARWV 2 is present in specimens R12 and R7 (Table 3), which suggests that either virus alone can cause ARWD. For a number of plant diseases, several distinct virus species are known to cause similar or identical symptoms; for example, little cherry disease can be caused by two distinct virus species (Jelkmann and Eastwell 2011) and grapevine leafroll disease can be caused by at least four distinct virus species (Martelli et al.
2012), all members of the family Closteroviridae. ARWV is a member of the order Bunyavirales of negative-sense RNA viruses (https:// talk.ictvonline.org/taxonomy/). Bunyavirus spp. typically have three distinct RNA segments (L, M, and S) whereas Emaravirus and Tenuivirus spp. have four distinct segments (RNA1 to RNA4). For ARWV, three distinct segments were discovered and characterized. A fourth segment, if present, was not detected. Characteristic of multisegmented negative-strand RNA viruses, all three ARWV RNA segments have conserved $5^{\prime}$ and $3^{\prime}$ inverted complimentary sequences. All segments, as determined from the NGS data, have the same 9 to $10 \mathrm{nt}$ at the $5^{\prime}$ and $3^{\prime}$ ends. The terminal sequences were confirmed and extended an additional $8 \mathrm{nt}$ for ARWV $2 \mathrm{Mb}$. These $8 \mathrm{nt}$ match the terminal $8 \mathrm{nt}$ for phlebo-, tenui-, and the recently sequenced, unclassified bunyavirus, citrus concave gum-associated virus (CCGaV) (Fig. 2). The presence of these inverted repeats indicates that the full coding regions of the RNA were obtained (Kulshreshtha et al. 2010). It is thought that these sequences result in the circularization of the bunyavirus viral RNA when packaged into virions (Hewlett et al. 1977). The presence of these repeated noncoding elements indicates that the full coding sequences for the ARWV segments was obtained. ARWV 2 has two distinct $\mathrm{M}$ and two distinct $\mathrm{S}$ segments associated with a single $\mathrm{L}$ segment. To differentiate the ARWV $2 \mathrm{M}$ and S segments, they were arbitrarily named $2 \mathrm{Ma}, 2 \mathrm{Mb}, 2 \mathrm{Sa}$, and $2 \mathrm{Sb}$. In four of the six sequenced specimens, these segments could be found in several combinations (Table 3). The phylogenetic relationship between the ARWV S and M segments indicated a comparable distance between $1 \mathrm{~S}, 2 \mathrm{Sa}$, and $2 \mathrm{Sb}$ and between $1 \mathrm{M}, 2 \mathrm{Ma}$, and $2 \mathrm{Mb}$ segments (Fig. 3), suggesting three distinct parental viruses. In the specimens tested thus far, a third distinct $\mathrm{L}$ segment could not be identified. It is possible that, during the evolution of these viruses, mixed infections of two virus species resulted in the reassortment of segments and a loss of one of the $\mathrm{L}$ segments, giving rise to present-day ARWV 2. Alternatively, a third L RNA segment may still await discovery. Specimen 982 is infected with ARWV 1 (1L, 1M, and 1S segments) and ARWV 2 (2L and $2 \mathrm{Sb}$ segments). We were unable to detect a $2 \mathrm{M}$ segment in 982, which could suggest that the 1M segment functions for both viruses. Reassortment is thought to be common in bunyaviruses (Briese et al. 2013) and has been observed among orthobunyvirus (Briese et al. 2006) and phleboviruses (Collao et al. 2010; Palacios et al. 2011), which would support the ARWV findings.

The family Bunyaviridae has recently been reclassified (https:// talk.ictvonline.org/taxonomy/) into the order Bunyavirales, with nine new families: Feraviridae, Phenuiviridae, Fimoviridae, Hantaviridae, Jonviridae, Nairoviridae, Peribunyaviridae, Phasmaviridae, and Tospoviridae. Three of these families include plant viruses: Tospoviridae, genus Orthotospovirus; Fimioviridae, genus Emaravirus; and Phenuiviridae, genera Phlebovirus and Tenuivirus. The genomic organization of plant bunyaviruses is diverse. The bunyavirus L segment codes for the viral replicase. High amino acid sequence homology was detected between the ARWV L protein and several recently sequenced plant and animal phleboviruses and would suggest that ARWV be classified within the family Phenuiviridae.

The bunyavirus $\mathrm{M}$ segment typically codes for glycoproteins $\mathrm{Gn}$ and $\mathrm{Gc}$, which form a dimer associated with the host membrane and assist with endocytosis of virus vesicles into the host cell (Murphy et al. 2012). Members of the genus Tenuivirus are an exception and can lack these proteins (Falk and Tsai 1998). The M segment can also code for a nonstructural (NSm) protein. For tospo- and tenuiviruses, the M RNA can be ambisense. The fusion and budding of envelope viruses from host cells is not a mechanism of virus movement between plant cells which are surrounded by a cell wall. Tomato spotted wilt virus Gn and Gc glycoproteins are thought to play a vital role in vector transmission of the virus by thrips (Ullman et al. 1993), while the NSm protein is involved in plant cell-to-cell and long-distance movement in the plant (Soellick et al. 2000). There is no record of ARWD transmission by insects or other natural vectors; vegetative propagation practices are the only known means of virus transmission. Therefore, it is interesting that the ARWV M segment does not code for a glycoprotein. It is possible that, when ARWD lost the ability to be naturally vectored, it also lost the Gn and Gc glycoproteins. Alternatively, it is still possible that a fourth RNA segment coding for membrane-bound glycoproteins 
remains to be discovered. The ARWV M segment NSm protein is most closely related to the $30 \mathrm{~K}$ viral movement protein superfamily that includes the Pfam families Tenui_NS4 and Emaravirus_P4, characteristic of tenuiviruses and emaraviruses, respectively. Although homology is low, homologs of the $30 \mathrm{~K}$ protein are known to display varying degrees of sequence similarity, and can also be found integrated in plant genomes (Mushegian and Elena 2015). The 30K protein forms a complex with viral genomic RNA to facilitate transport through plasmodesmata.

Both the Phlenuiviridae and Tospoviridae families have ambisense $\mathrm{S}$ RNA segments, coding for the viral $\mathrm{N}$ protein and a small nonstructural (NSs) protein thought to be involved in suppression of RNA silencing (Oliveira et al. 2011). Bioinformatic analysis suggests that a single ORF on the ARWV S segment codes for the viral $\mathrm{N}$ protein with homology to other viruses of the family Phlenuiviridae. An NSs protein analog is not present. Not all viruses of the order Bunyavirales code for an NSs protein; therefore, this is not unusual. Both Emaravirus and Tenuivirus spp. code for additional NSs proteins on a fourth RNA segment; thus, the ARWV genome may consist of additional RNA segments that remains to be discovered.

The distinct features of ARWV support the conclusion that it is a unique member of the order Bunyavirales and should be classified as a new genus under the family Phenuiviridae. To facilitate the inclusion of ARWV as a member of the Phenuiviridae, we suggest that the new genera Rubodvirus (for "rubbery wood") be established.

Identification of novel organisms, including viruses from NGS data, are often accomplished by de novo contig assembly and the use of BLASTX to identify distantly related viruses using a reference sequence database. This was unsuccessful in identifying ARWV using the exact same data from one of the specimens in this study (Jakovljevic et al. 2016). Due to limitations in the BLAST algorithm, this method is effective for the detection of more distantly related relatives of known viruses. Using an alternative method based on profile HMM and a specific database of viral protein motifs, vFam (Eddy 2011; Johnson et al. 2010), it was possible to very rapidly identify full-length sequences for all three components of ARWV. A workflow called $\mathrm{NuVs}$ was developed for the rapid detection of novel viruses using HMMER and vFam, as part of a larger piece of software called Virtool, for management and analysis of NGS data for plant virus detection (https://www.virtool.ca).

\section{Acknowledgments}

We thank A. Gratz.

\section{Literature Cited}

Al Rwahnih, M., Daubert, S., Úrbez-Torres, J. R., Cordero, F., and Rowhani, A. 2011. Deep sequencing evidence from single grapevine plants reveals a virome dominated by mycoviruses. Arch. Virol. 156:397-403.

Argos, P. 1988. A sequence motif in many polymerases. Nucleic Acids Res. 16: 9909-9916.

Bankevich, A., Nurk, S., Antipov, D., Gurevich, A. A., Dvorkin, M., Kulikov, A. S., Lesin, V. M., Nikolenko, S. I., Pham, S., Prjibelski, A. D., Pyshkin, A. V., Sirotkin, A. V., Vyahhi, N., Tesler, G., Alekseyev, M. A., and Pevzner, P. A. 2012. SPAdes: A new genome assembly algorithm and its applications to single-cell sequencing. J. Comput. Biol. 19:455-477.

Beakbane, A. B., Mishra, M. D., Posnette, A. F., and Slater, C. H. W. 1971. Mycoplasma-like organisms associated with chat fruit and rubbery wood diseases of apple, Malus domestica Borkh., compared with those in strawberry with green petal disease. J. Gen. Microbiol. 66:55-62.

Beakbane, A. B., and Thompson, E. C. 1945. Abnormal lignification in the wood of some apple trees. Nature 156:145-146.

Bertaccini, A., Vibio, M., Franova-Honetslegrova, J., and Janeckova, M. 1998. Molecular detection of phytoplasmas in apple with rubbery wood symptoms. Acta Hortic. 472:693-700.

Briese, T., Bird, B., Kapoor, V., Nichol, S. T., and Lipkin, W. I. 2006. Batai and Ngari viruses: $M$ segment reassortment and association with severe febrile disease outbreaks in East Africa. J. Virol. 80:5627-5630.

Briese, T., Calisher, C. H., and Higgs, S. 2013. Viruses of the family Bunyaviridae: Are all available isolates reassortants? Virology 446:207-216.

Campbell, A. I. 1966. The growth of young pears after elimination of some viruses by heat treatment. Long Ashton Res. Stn. Rep. 1965:111-116.

Chamberlain, E. E., Atkinson, J. D., Wood, G. A., and Hunter, J. A. 1971. Apple rubbery wood virus. N. Z. J. Agric. Res. 14:707-719.

Collao, X., Palacios, G., de Ory, F., Sanbonmatsu, S., Perez-Ruiz, M., Navarro, J. M., Molina, R., Hutchison, S. K., Lipkin, W. I., Tenorio, A., and Sanchez-Seco,
M. P. 2010. Granada virus: A natural phlebovirus reassortant of the sandfly fever Naples serocomplex with low seroprevalence in humans. Am. J. Trop. Med. Hyg. 83:760-765.

Cropley, R., Wolfswinkel, L. D., and Posnette, A. F. 1963. The identification of some viruses in apple, pear and quince. Phytopathol. Mediterr. 2:132-136.

Eddy, S. R. 2011. Accelerated profile HMM searches. PLOS Comput. Biol. 7: e1002195.

EPPO. 1999. Certification schemes-Pathogen-tested material of Malus pyrus Cydonia. EPPO Bull. 29:239-252.

Falk, B. W., and Tsai, J. H. 1998. Biology and molecular biology of viruses in the genus Tenuivirus. Annu. Rev. Phytopathol. 36:139-163.

Hewlett, M. J., Pettersson, R. F., and Baltimore, D. 1977. Circular forms of Uukuniemi virion RNA: An electron microscopic study. J. Virol. 21:1085-1093.

Jakovljevic, V., Otten, P., Berwarth, C., and Jelkmann, W. 2016. Analysis of the apple rubbery wood disease by next generation sequencing of total RNA. Eur. J. Plant Pathol. 148:637-646.

Jelkmann, W., and Eastwell, K. C. 2011. Little cherry virus -1 and -2. Pages 153-160: Virus and Virus-Like Diseases of Pome and Stone Fruits. A. Hadidi, M. Barba, T Candresse, and W. Jelkmann, eds. American Phytopathological Society, St. Paul, MN.

Johnson, L. S., Eddy, S. R., and Portugaly, E. 2010. Hidden Markov model speed heuristic and iterative HMM search procedure. BMC Bioinf. 11:431.

Kesanakurti, P., Belton, M., Saeed, H., Rast, H., Boyes, I., and Rott, M. 2016. Screening for plant viruses by next generation sequencing using a modified double strand RNA extraction protocol with an internal amplification control. J. Virol. Methods 236:35-40.

Kulshreshtha, V., Kibenge, M., Salonius, K., Simard, N., Riveroll, A., and Kibenge, F. 2010. Identification of the $3^{\prime}$ and $5^{\prime}$ terminal sequences of the 8 rna genome segments of European and North American genotypes of infectious salmon anemia virus (an orthomyxovirus) and evidence for quasispecies based on the non-coding sequences of transcripts. J. Virol. 7:338.

Langmead, B., and Salzberg, S. L. 2012. Fast gapped-read alignment with Bowtie 2. Nat. Methods 9:357-359.

Lemoine, J., and Michelesi, J. C. 1990. Effects of three virus-diseases on three pear cultivars. Sci. Hortic. (Amsterdam) 44:69-81.

Martelli, G. P., Abou Ghanem-Sabanadzovic, N., Agranovsky, A. A., Al Rwahnih, M., Dolja, V. V., Dovas, C. I., Fuchs, M., Gugerli, P., Hu, J. S., Jelkmann, W., Katis, N., Maliogka, V. I., Melzer, M. J., Menzel, W., Minafra, A., Rott, M. E., Rowhani, A., Sabanadzovic, S., and Saldarelli, P. 2012. Taxonomic revision of the family Closteroviridae with special reference to the grapevine leafrollassociated members of the genus Amplelovirus and the putative species unassigned to the family. J. Plant Pathol. 94:7-19.

McCrum, R. C., Barrat, J. G., Hilborn, M. T., and Rich, A. E. 1960. An Illustrated Review of Apple Virus Diseases. Maine Agricultural Experiment Station Bulletin 595 and New Hampshire Agricultural Experiment Station Technical Bulletin 101.

Menzel, W., Zahn, V., and Maiss, E. 2003. Multiplex RT-PCR-ELISA compared with bioassay for the detection of four apple viruses. J. Virol. Methods 110:153-157.

Minoui, N., and Cracium, C. 1982. Electron microscopy detection of apple rubbery wood pathogens and cobalt-therapy of infected fruit trees. Acta Hortic. 130: 313-315.

Murphy, F. A., Fauquet, C. M., Bishop, D. H. L., Ghabrial, S. A., Jarvis, A., Martelli, G. P., Mayo, M. A., and Summers, M. D. 2012. Virus Taxonomy: Classification and Nomenclature of Viruses. Springer, Vienna.

Mushegian, A. R., and Elena, S. F. 2015. Evolution of plant virus movement proteins from the $30 \mathrm{~K}$ superfamily and of their homologs integrated in plant genomes. Virology 476:304-315.

Németh, M. V. 1986. The Virus, Mycoplasma and Rickettsia Diseases of Fruit Trees. Martinus Nijhoff, Dordrecht, The Netherlands.

Oliveira, V. C., Bartasson, L., de Castro, M. E., Correa, J. R., Ribeiro, B. M., and Resende, R. O. 2011. A silencing suppressor protein (NSs) of a tospovirus enhances baculovirus replication in permissive and semipermissive insect cell lines. Virus Res. 155:259-267.

Palacios, G., Tesh, R., Travassos da Rosa, A., Savji, N., Sze, W., Jain, K., Serge, R., Guzman, H., Guevara, C., Nunes, M. R., Nunes-Neto, J. P., Kochel, T., Hutchison, S., Vasconcelos, P. F., and Lipkin, W. I. 2011. Characterization of the Candiru antigenic complex (Bunyaviridae: Phlebovirus), a highly diverse and reassorting group of viruses affecting humans in tropical. Am. J. Virol. 85:3811-3820.

Pettersson, R. F., and von Bonsdorff, C. H. 1975. Ribonucleoproteins of Uukuniemi virus are circular. J. Virol. 15:386-392.

Poggi Pollini, C., Giunchedi, L., Filippini, G., Seemüller, E., and Vindimian, G. 1995. Etiological studies of apple rubbery wood disease. Acta Hortic. 386: 503-505.

Rott, M., Xiang, Y., Boyes, I., Belton, M., Saeed, H., Kesanakurti, S., Hayes, T., Lawrence, T., Birch, C., Bhagwat, B., and Rast, H. 2017. Application of next generation sequencing for diagnostic testing of tree fruit viruses and viroids. Plant Dis. 101:1489-1499.

Rott, M. E., and Jelkmann, W. 2001. Characterization and detection of several filamentous viruses of cherry: Adaptation of an alternative cloning method (DOP-PCR), and modification of an RNA extraction protocol. Eur. J. Plant Pathol. 107:411-420.

Skewes-Cox, P., Sharpton, T. J., Pollard, K. S., and DeRisi, J. L. 2014. Profile hidden Markov models for the detection of viruses within metagenomic sequence data. PLoS One 9:e105067. 
Smart, C. D., Schneider, B., Blomquist, C. L., Guerra, L. J., Harrison, N. A., Ahrens, U., Lorenz, K. H., Seemuller, E., and Kirkpatrick, B. C. 1996. Phytoplasma-specific PCR primers based on sequences of the 16S-23S rRNA spacer region. Appl. Environ. Microbiol. 62:2988-2993.

Soellick, T. R., Uhrig, J. F., Bucher, G. L., Kellmann, J. W., and Schreier, P. H. 2000. The movement protein NSm of tomato spotted wilt tospovirus (TSWV): RNA binding, interaction with the TSWV $\mathrm{N}$ protein, and identification of interacting plant proteins. Proc. Natl. Acad. Sci. USA 97:2373-2378.

Thomas, H. E. 1942. Transmissible rough-bark diseases of fruit trees. Phytopathology 32:435-436.

Ullman, D. E., German, T. L., Sherwood, J. L., Westcot, D. M., and Cantone, F. A. 1993. Tospovirus replication in insect vector cells: Immunocytochemical evidence that the nonstructural protein encoded by the S RNA of tomato spotted wilt tospovirus is present in thrips vector cells. Phytopathology 83: 456-463.

Velasco, R., Zharkikh, A., Affourtit, J., Dhingra, A., Cestaro, A., Kalyanaraman, A., Fontana, P., Bhatnagar, S. K., Troggio, M., Pruss, D., Salvi, S., Pindo, M., Baldi, P., Castelletti, S., Cavaiuolo, M., Coppola, G., Costa, F., Cova, V., Dal Ri, A., Goremykin, V., Komjanc, M., Longhi, S., Magnago, P., Malacarne, G., Malnoy, M., Micheletti, D., Moretto, M., Perazzolli, M., Si-Ammour, A.,
Vezzulli, S., Zini, E., Eldredge, G., Fitzgerald, L. M., Gutin, N., Lanchbury, J., Macalma, T., Mitchell, J. T., Reid, J., Wardell, B., Kodira, C., Chen, Z., Desany, B., Niazi, F., Palmer, M., Koepke, T., Jiwan, D., Schaeffer, S., Krishnan, V., Wu, C., Chu, V. T., King, S. T., Vick, J., Tao, Q., Mraz, A., Stormo, A., Stormo, K., Bogden, R., Ederle, D., Stella, A., Vecchietti, A., Kater, M. M., Masiero, S., Lasserre, P., Lespinasse, Y., Allan, A. C., Bus, V., Chagne, D., Crowhurst, R. N., Gleave, A. P., Lavezzo, E., Fawcett, J. A. Proost, S., Rouze, P., Sterck, L., Toppo, S., Lazzari, B., Hellens, R. P., Durel, C.-E., Gutin, A., Bumgarner, R. E., Gardiner, S. E., Skolnick, M., Egholm, M., Van de Peer, Y., Salamini, F., and Viola, R. 2010. The genome of the domesticated apple (Malus $\times$ domestica Borkh.). Nat. Genet. 42:833-839.

Wallace, T., Swarbrick, T., and Ogilvie, L. 1944. Some new troubles in the apples with special reference to the variety Lord Lambourne. Fruitgrower 98:427.

Waterworth, H. E., and Fridlund, P. R. 1989. Viruslike diseases of quince. Pages 213-217 in: Virus and Viruslike Diseases of Pome Fruits and Simulating Noninfectious Disorders. P. R. Fridlund, ed. Cooperative Extension College of Agriculture and Home Economics, Washington State University, Pullman.

Zawadzka, B. J., Rebandel, Z., and Wierszyllowski, J. 1979. The rate of transmission of latent apple viruses and rubbery wood disease pathogen from the infected bud to the indicator plant. Fruit Sci. Rep. 6:177-183. 